\title{
Benchmarking the scientific output of industrial wastewater research in Arab world by utilizing bibliometric techniques
}

\author{
Shaher H. Zyoud ${ }^{1}$ - Aiman E. Al-Rawajfeh ${ }^{2,3} \cdot$ Hafez Q. Shaheen ${ }^{4}$. \\ Daniela Fuchs-Hanusch ${ }^{1}$
}

Received: 22 October 2015 / Accepted: 7 March 2016/Published online: 21 March 2016

(C) The Author(s) 2016. This article is published with open access at Springerlink.com

\begin{abstract}
Rapid population growth, worsening of the climate, and severity of freshwater scarcity are global challenges. In Arab world countries, where water resources are becoming increasingly scarce, the recycling of industrial wastewater could improve the efficiency of freshwater use. The benchmarking of scientific output of industrial wastewater research in the Arab world is an initiative that could support in shaping up and improving future research activities. This study assesses the scientific output of industrial wastewater research in the Arab world. A total of 2032 documents related to industrial wastewater were retrieved from 152 journals indexed in the Scopus databases; this represents $3.6 \%$ of the global research
\end{abstract}

Responsible editor: Philippe Garrigues

Shaher H. Zyoud

shaherzyouds@gmail.com

Aiman E. Al-Rawajfeh

aimanr@yahoo.com

Hafez Q. Shaheen

shaheen@najah.edu

Daniela Fuchs-Hanusch

fuchs-hanusch@tugraz.at

1 Institute of Urban Water Management and Landscape Water Engineering, Graz University of Technology, Stremayrgasse 10/I, A-8010 Graz, Austria

2 Chemical Engineering Department, The University of Jordan, Amman, Jordan

3 Chemical Engineering Department, Tafila Technical University, Tafila, Jordan

4 Civil Engineering Department, An-Najah National University, Nablus, Palestine output. The $h$-index of the retrieved documents was 70 . The total number of citations, at the time of data analysis, was 34,296 with an average citation of 16.88 per document. Egypt, with a total publications of 655 (32.2\%), was ranked the first among the Arab countries followed by Saudi Arabia 300 (14.7\%) and Tunisia 297 (14.6 \%). Egypt also had the highest $h$-index, assumed with Saudi Arabia, the first place in collaboration with other countries. Seven hundred fifteen (35.2\%) documents with 66 countries in Arab/non-Arab country collaborations were identified. Arab researchers collaborated mostly with researchers from France 239 (11.7\%), followed by the USA 127 (6.2 \%). The top active journal was Desalination 126 $(6.2 \%)$, and the most productive institution was the National Research Center, Egypt 169 (8.3 \%), followed by the King Abdul-Aziz University, Saudi Arabia 75 (3.7\%). Environmental Science was the most prevalent field of interest $930(45.8 \%)$. Despite the promising indicators, there is a need to close the gap in research between the Arab world and the other nations. Optimizing the investments and developing regional experiences are key factors to promote the scientific research.

Keywords Arab world · Benchmarking · Bibliometrics · Industrial wastewater $\cdot$ Scopus $\cdot h$-index

\section{Introduction}

With continuing urbanization and industrialization across the globe, associated with increase in population, the pollution of aquatic environments caused by industrial wastewaters has increased and became a major environmental concern (Azizullah et al. 2015). Industrial wastewater acts as a major source of toxic organic compounds (Wu et al. 
2015) and heavy metals to natural waters (Abramov et al. 2014), which are of concern for public health (Phetphaisit et al. 2016). The uncontrolled disposal of industrial wastewaters often results in contamination of surface and groundwater and imbalance of ecosystems. In the developing world, $70 \%$ of untreated industrial wastewaters are released into surface water (Azizullah et al. 2015).

Major sources of industrial wastewater include iron and steel industry, mining, food industry, nuclear industry, complex organic chemical industry, textiles and leather, pulp and paper, microelectronics industry, and pharmaceutical industry (Lin et al. 2012). The characteristics of industrial wastewaters depend substantially on the industrial processes and the produced wastewater. These characteristics vary within each industry and diverse than the municipal/domestic wastewaters which have similar composition in terms of quality and quantity (Krzemińska et al. 2015).

The large variations in the composition and loads of industrial wastewaters, the presence of high concentrations of salts and organic matters, and the poorly biodegradable organic substances hinder treating these effectively (Dvořák et al. 2013; García-García et al. 2015; Szafnicki and Narce 2006). Therefore, industries and researchers devoted their efforts to develop technologies and processes characterized by higher efficiencies and inexpensive costs aiming to reduce the volumes of wastewater at source, to improve the quality of the effluents (Barakat 2011), and to meet the allowable maximum contaminant levels and standards.

The most prevalent techniques in industrial wastewater treatment realm comprise (a) adsorption which is a conventional method and a highly effective technique in removing heavy metals (Oke et al. 2008); (b) membrane separation which has been used recently for the treatment of inorganic effluent due to its convenient operation (Barakat 2011); (c) electro treatments such as electrodialysis, which is friendly for environment (Barakat 2011; Pedersen 2003); (d) photocatalytic which is an innovative and promising technique for efficient destruction of pollutants (Barakat 2011); (e) integration of electrooxidation and ozonation which is an advance technique to reduce the high organic load of industrial wastewater (García-Morales et al. 2013); (f) electrochemical advanced oxidation which is efficient in removing pharmaceuticals from water (Brillas and Sirés 2015); and (g) nanotechnology technique which is advancing (Roy and Bhattacharya 2015).

Up to date, the available treatment technologies experience series of technical and economic challenges with regard to developing effective techniques to reclaim the industrial effluents. This has led to extensive research to overcome the inherent limitations in the existing technologies (Roy and Bhattacharya 2015).

\section{Industrial wastewater research in the Arab world}

As water scarcity becomes a more pressing concern throughout the Arab world, water reuse is considered as a great potential in increasing water resources (World Bank 2011). The estimated amount of wastewater produced by the Arab world is $10.8 \mathrm{~km}^{3} /$ year (World Bank 2011). Researchers and policy makers are searching continuously for additional water sources. Reuse-treated wastewater and recycling the industrial wastewater in industrial sectors are now considered as supplementary sources with significant potential in alleviating water scarcity (Al-Zubari 1998).

Geographically, the Arab world lies between the Atlantic coasts of northern Africa and the Arabian Gulf (Saleh 2015). The 22 Arab countries, with approximately 370 million individuals, comprise a region with great diversity in socioeconomic conditions, but there are important commonalities in language, culture, religion, and demographics (Obermeyer et al. 2015). Since two decades, the scientific research in the Arab region has shown a general trend of growth (Waast and Rossi 2010) and the research productivity has increased from $0.6 \%$ out of global productivity in 1981 to $0.9 \%$ in 2000 (UIS 2005). The recent development in living standards, educational levels, and health services in most of Arab countries has been associated with the progress in scientific research (Benamer and Bakoush 2009). The negligence of science in this region which has a historical and catalytic role in the scientific revolution in its early stages (Maziak 2005) and a proud history of scholarship is dwindling, and grassroot initiatives with a hope in restoring the balance are witnessed (Masood 2002). The spending on research and development is on the rise (Masood 2002).

The assessment of the Arab world's contribution in industrial wastewater research through mapping the productivity of research will help in identifying the existing research directions and the state of research with comparison to other nations. It will assist future research investments since the advances in sciences and technologies are becoming rapidly important for regional competitiveness and economic growth (Minguillo et al. 2015). Bibliometric techniques, which mainly utilize quantitative analysis and statistical indices to evaluate research productivity of individuals, institutes, or countries, are valuable tools in measuring the scientific research productivity (Wallin 2005). These tools can be used to make pronouncements about qualitative pictures of scientific activities (Wallin 2005). A good knowledge and information related to the state of research in a particular discipline, which could assist the researchers to identify and conduct new lines of research, can be derived from the output measurements of the bibliometric techniques (De Battisti and Salini 2013). These techniques are well-known research procedures with high potential to perform systematic analyses (van Raan 2005). 
By reviewing the available literature, and up to the authors' knowledge, the evaluation of research productivity related to industrial wastewater research in the Arab world has not been addressed. Globally, many studies have tackled this issue including Zheng et al. (2015) and Qian et al. (2015), respectively. The first has evaluated industrial wastewater treatment research from 1991 to 2014 based on data from the Science Citation Index Expanded database (Zheng et al. 2015). The second study has evaluated the research patterns and tendencies of pharmaceutical wastewater treatment from 1994 to 2013 based on data from the Science Citation Index Expanded database and Web of Science (Qian et al. 2015).

Our main objective is to analyze the research productivity of the Arab world in industrial wastewater. This analysis will lead to better understanding of the current status of industrial wastewater research in the Arab world. It aims in helping researchers and policy makers in shaping future research activities.

\section{Methodology}

The data used in this study was harvested from Scopus databases. These databases are considered one of the largest databases of peer-reviewed literature, include more than 57 million records, and cover over 21,000 peer-reviewed journals (Elsevier 2015). All Arab countries within Arab league, Saudi Arabia, Egypt, Jordan, Palestine, Lebanon, Qatar, Bahrain, Kuwait, Morocco, Tunisia, Syrian Arab Republic, United Arab Emirates, Iraq, Sudan, Yemen, Algeria, Comoros, Djibouti, Libya, Mauritania, Oman, and Somalia, are used as country keys in this study. The search covered all subject areas within Scopus that comprise health, social, life, and physical sciences. The output of scientific research after the year 2014 has been excluded because the period after December 31, 2013 is still open for new publications. The search was implemented one time on October 5, 2015 to eliminate the bias which may appear because of continuous updating of Scopus databases.

The search expression used in the advanced search is the same used in the study, which has been conducted by Zheng et al. (2015), to evaluate the scientific research productivity in industrial wastewater treatment. We kept the lower boundary of the search period as an open interval, and the upper is the end of the year 2013. The analysis was limited to articles and review articles and has excluded all other types of publications such as books and conference papers. The topic search contains the fields of each paper's title and abstract. The search query appeared like the following pattern in the advanced search: TITLE OR ABS (industrial OR industry) AND (sewage* OR effluent* OR wastewater* OR (waste water*) OR waste-water*) AND PUBYEAR $<2014$ AND (EXCLUDE (DOCTYPE, “cp”) OR EXCLUDE (DOCTYPE, “ch") OR
EXCLUDE (DOCTYPE, "bk") OR EXCLUDE (DOCTYPE, “cr") OR EXCLUDE (DOCTYPE, "no") OR EXCLUDE (DOCTYPE, "sh") OR EXCLUDE (DOCTYPE, "bz") OR EXCLUDE (DOCTYPE, “rp") OR EXCLUDE (DOCTYPE, “ed") OR EXCLUDE (DOCTYPE, “ab") OR EXCLUDE (DOCTYPE, "le") OR EXCLUDE (DOCTYPE, “er") OR EXCLUDE (DOCTYPE, "Undefined")) AND (LIMIT-TO (AFFILCOUNTRY, "Egypt") OR LIMIT-TO (AFFILCOUNTRY, "Saudi Arabia") OR LIMIT-TO (AFFILCOUNTRY, “Tunisia”) OR LIMIT-TO (AFFILCOUNTRY, "Algeria”) OR LIMIT-TO (AFFILCOUNTRY, "Morocco") OR LIMIT-TO (AFFILCOUNTRY, "Jordan") OR LIMIT-TO (AFFILCOUNTRY, "United Arab Emirates") OR LIMITTO (AFFILCOUNTRY, "Kuwait") OR LIMIT-TO (AFFILCOUNTRY, "Oman") OR LIMIT-TO (AFFILCOUNTRY, "Lebanon") OR LIMIT-TO (AFFILCOUNTRY, “Q atar") OR LIMIT-TO (AFFILCOUNTRY, "Iraq") OR LIMIT-TO (AFFILCOUNTRY, "Palestine") OR LIMIT-TO (AFFILCOUNTRY, "Syrian Arab Republic") OR LIMITTO (AFFILCOUNTRY, "Libyan Arab Jamahiriya”) OR LIMIT-TO (AFFILCOUNTRY, "Bahrain") OR LIMIT-TO (AFFILCOUNTRY, "Yemen") OR LIMIT-TO (AFFILCOUNTRY, "Sudan")).

Through analyzing and auditing the list of countries from the global, four Arab countries did not have any contribution toward research articles related to industrial wastewater. They are Comoros, Djibouti, Mauritania, and Somalia. The output data have been analyzed to create a perspective about (a) research productivity in industrial wastewater research, (b) collaboration patterns between the Arab countries and the world, (c) citations of the published research, (d) journals in which researchers from Arab world have published their works, and (e) comparative study with other nations in the same region (Turkey, Israel, and Iran), which was done to measure the performance of Arab countries in industrial wastewater research as the base in benchmarking analysis.

The top ten ranked outputs from the bibliometric measurements (countries, institutions, areas of interests, and cited articles) are displayed. They attract ranking in order of descending according to the formula of standard competition ranking (SCR). In case two measurements attracted the same ranking, a gap has to be considered for the following numbers.

The $h$-index, which represents an indicator with a potential to incorporate both quantity (publication) and quality (citation scores) measures (Egghe 2006), has been extracted to demonstrate the total citations of the published works. This index was proposed to characterize the importance, significance, and broad impact of a researcher's cumulative research contributions (Hirsch 2005) and to qualify the performance of research (Meho and Rogers 2008). To illustrate its concept 
on testing a country's scientific impact and productivity, a country with $h$-index 30 has published 30 documents and each document has gained at least 30 citations. Journal Citation Report (JCR; Web of Knowledge 2014) has been employed to display the impact factor (IF) of the journals and considered top ten ranked journals.

The Statistical Package for Social Sciences (SPSS) program version 20 has been used to calculate statistic measurements, which comprise descriptive statistic components, such as median, mean, and sum, and the median (Q1-Q3 interquartile range).

\section{Results}

At global level, the total number of retrieved documents from Scopus databases was 78,836 documents and the exclusion of all types of publications except the articles and review articles lead to a total of 57,235 documents. By limiting the search to articles and review articles that have been published by researchers from the Arab world, the total output was 2032 documents. This figure represents $3.6 \%$ of the global research productivity in the fields of industrial wastewater.

The industrial wastewater research activities by researchers in the Arab world have begun in 1976. The productivity grew at a very modest rate and breakthrough has occurred in 2001, as shown in Fig. 1. More than $90 \%$ of the articles were published after the year 2001. The first published article was in the International Journal of Mineral Processing by Doheim, M.A. from the Faculty of Engineering, Assiut University, Egypt, entitled "Fluidization in the non-ferrous mineral processing and metal industry" (Doheim 1976). At global level, the first published work as documented in Scopus databases was in 1931 in the Journal of Chemical Education by Arnold, L.K. from Engineering Experiment Station, Iowa State
College, USA, entitled "Agricultural wastes in industry" (Arnold 1931).

The analysis of the used language in the published works shows that the English language is predominant (1957; $96.3 \%$ ), followed in far away by French $(80 ; 3.9 \%)$, Spanish (6; $0.3 \%)$, Italian ( $2 ; 0.1 \%)$, and Korean $(1 ; 0.05 \%)$.

The analyzing of data for countries of the Arab world (Table 1) shows that 18 countries out of 22 of the Arab world league have contributions in industrial wastewater research. Their contributions and collaboration patterns with other countries and citation rates vary from one country to another. Egypt had the highest research output $(655 ; 32.23 \%)$, followed by Saudi Arabia (300; $14.76 \%$ ), Tunisia (297; $14.62 \%$ ), and Algeria (200; $9.84 \%$ ). The total number of citations at the time of processing the analysis (October 5, 2015) was 34,296, with a mean of 16.88 and a median (interquartile range) of 6 (1.0-16.0). At country level, Egypt had the highest number of citations (8044), followed by Tunisia (6171), Saudi Arabia (5104), and Morocco (4249). The $h$-index of the total retrieved documents was 70 , which means that 70 documents had attracted at least 70 citations to the time of data analysis. The highest $h$-index was 43 for Egypt, followed by 36 for Saudi Arabia, and 35 for Tunisia.

Table 2 lists the regions and countries of the world whose researchers have collaborations with researchers from the Arab world in industrial wastewater research. The study identified 715 (35.19\%) documents with 66 countries in the Arab world collaboration with non-Arab countries. At regional level, Arab researchers collaborated mostly with researchers from Western Europe (423; $20.82 \%$ ), followed by researchers from Northern America (166; $8.17 \%$ ) and Asiatic region (152; $7.48 \%$ ). At county level, France recorded the high rate of collaboration with the Arab world $(n=239)$, followed by the USA $(n=127)$, UK $(n=57)$, and India $(n=52)$. The highest $h$-index for the published works in the Arab world collaboration with non-Arab countries
Fig. 1 Number of published articles and review articles from the Arab world and global in industrial wastewater research

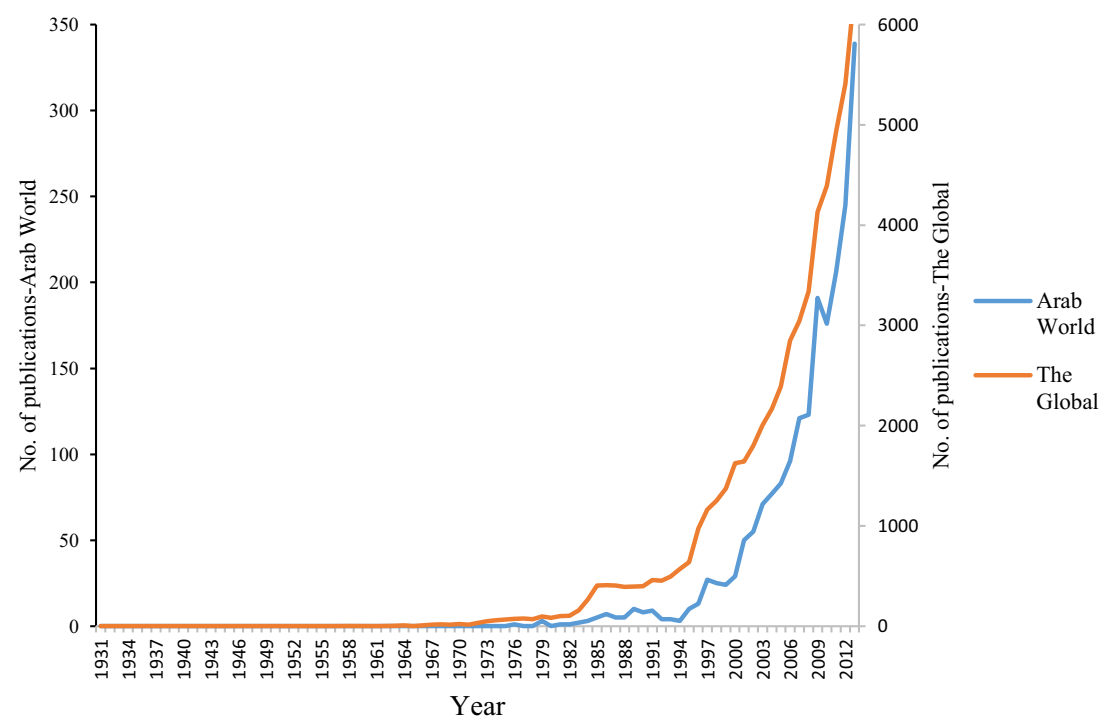


Table 1 Bibliometric analysis of the 2032 documents associated with industrial wastewater research output by Arab countries

\begin{tabular}{|c|c|c|c|c|c|c|c|c|c|c|}
\hline $\mathrm{SCR}^{\mathrm{a}}$ & Countries & $\begin{array}{l}\text { Articles } \\
(\%)\end{array}$ & $\begin{array}{l}h- \\
\text { index }\end{array}$ & $\begin{array}{l}\text { No. of } \\
\text { citations }\end{array}$ & $\begin{array}{l}\text { Median } \\
\text { citation } \\
(\mathrm{Q} 1-\mathrm{Q} 3)\end{array}$ & $\begin{array}{l}\text { Average } \\
\text { citation }\end{array}$ & $\begin{array}{l}\text { Collaborations } \\
\text { with } \\
\text { other } \\
\text { countries }\end{array}$ & $\begin{array}{l}\text { Number }(\%)^{\mathrm{b}} \text { of } \\
\text { documents with } \\
\text { international } \\
\text { authors }\end{array}$ & $\begin{array}{l}\text { Most } \\
\text { collaborated } \\
\text { country }\end{array}$ & $\begin{array}{l}\text { No. of documents } \\
\text { with most } \\
\text { collaborated } \\
\text { country }(\%)\end{array}$ \\
\hline 1 st & Egypt & $\begin{array}{l}655 \\
\quad(32.23)\end{array}$ & 43 & 8044 & $4(1.0-14.0)$ & 12.28 & 42 & 183 (27.9) & $\begin{array}{l}\text { Saudi } \\
\text { Arabia }\end{array}$ & $55(8.4)$ \\
\hline 2nd & $\begin{array}{l}\text { Saudi } \\
\quad \text { Arabia }\end{array}$ & $\begin{array}{l}300 \\
\quad(14.76)\end{array}$ & 36 & 5104 & $\begin{array}{c}6.5(2.0- \\
16.0)\end{array}$ & 17.01 & 42 & 179 (59.7) & Egypt & $55(18.3)$ \\
\hline $3 \mathrm{rd}$ & Tunisia & $\begin{array}{l}297 \\
\quad(14.62)\end{array}$ & 35 & 6171 & $9(3.0-20.0)$ & 20.78 & 31 & $139(46.8)$ & France & $78(26.3)$ \\
\hline 4th & Algeria & $\begin{array}{l}200 \\
\quad(9.84)\end{array}$ & 23 & 2240 & $\begin{array}{l}4(1.0- \\
14.75)\end{array}$ & 11.2 & 20 & $95(47.5)$ & France & 77 (38.5) \\
\hline 5 th & Morocco & $\begin{array}{l}172 \\
\quad(8.46)\end{array}$ & 27 & 4249 & $\begin{array}{c}5.5(1.0- \\
17.0)\end{array}$ & 24.7 & 22 & $101(58.7)$ & France & $63(36.6)$ \\
\hline 6th & Jordan & $\begin{array}{l}133 \\
(6.55)\end{array}$ & 22 & 1790 & $6(1.5-18.0)$ & 13.46 & 29 & $51(38.3)$ & USA & $12(9.0)$ \\
\hline 7 th & $\begin{array}{l}\text { United } \\
\text { Arab } \\
\text { Emirates }\end{array}$ & $96(4.72)$ & 21 & 4120 & $\begin{array}{c}8.5(3.0- \\
18.0)\end{array}$ & 42.92 & 22 & $59(61.5)$ & USA & $10(10.4)$ \\
\hline 8th & Kuwait & $74(3.64)$ & 16 & 873 & $\begin{array}{c}3(1.0- \\
14.25)\end{array}$ & 11.8 & 21 & $23(31.1)$ & Canada & $5(6.8)$ \\
\hline 9th & Oman & $41(2.02)$ & 13 & 603 & $7(2.0-18.5)$ & 14.71 & 24 & 27 (65.9) & USA & $5(12.2)$ \\
\hline 10th & Lebanon & 39 (1.92) & 13 & 621 & $9(3.0-18.0)$ & 15.92 & 12 & 27 (69.2) & France & $12(30.8)$ \\
\hline 11th & Qatar & 38 (1.87) & 17 & 634 & $9(1.0-26.5)$ & 16.68 & 21 & 31 (81.6) & Egypt & $8(21.1)$ \\
\hline 12th & Iraq & 35 (1.72) & 8 & 221 & $4(0.0-5.0)$ & 6.31 & 9 & $13(37.1)$ & Malaysia & $3(8.6)$ \\
\hline 13th & Palestine & $32(1.57)$ & 10 & 372 & $4(2.0-13.0)$ & 11.63 & 12 & $19(59.4)$ & USA & $6(18.8)$ \\
\hline 14th & $\begin{array}{l}\text { Syria Arab } \\
\text { Republic }\end{array}$ & $26(1.28)$ & 13 & 729 & $\begin{array}{r}11(3.75- \\
29.25)\end{array}$ & 28.04 & 16 & $14(53.8)$ & Sri Lanka & $6(23.1)$ \\
\hline 15 th & $\begin{array}{l}\text { Libyan } \\
\text { Arab } \\
\text { Jamahiriya }\end{array}$ & $17(0.84)$ & 6 & 88 & $3(0.5-7.0)$ & 5.17 & 8 & $8(47.1)$ & Egypt & $2(11.8)$ \\
\hline 15th & Bahrain & $17(0.84)$ & 10 & 292 & $\begin{array}{r}11(1.5- \\
20.0)\end{array}$ & 17.18 & 15 & $5(29.4)$ & France & $2(11.8)$ \\
\hline 17th & Yemen & $9(0.44)$ & 4 & 271 & $4(1.0-10.5)$ & 30.11 & 9 & $6(66.7)$ & Iraq & $2(22.2)$ \\
\hline 18th & Sudan & $8(0.39)$ & 4 & 89 & $\begin{array}{c}3(1.25- \\
12.75)\end{array}$ & 11.13 & 19 & $5(62.5)$ & India & $2(25.0)$ \\
\hline 19th & Mauritania & - & - & - & - & - & - & - & - & - \\
\hline 19th & Djibouti & - & - & - & - & - & - & - & - & - \\
\hline 19th & Somalia & - & - & - & - & - & - & - & - & - \\
\hline 19th & Comoros & - & - & - & - & - & - & - & - & - \\
\hline
\end{tabular}

SCR standard competition ranking, Q1-Q3 lower quartile-upper quartile

${ }^{a}$ Equal countries have the same ranking number, and then, a gap is left in the ranking numbers

${ }^{\mathrm{b}}$ Percentage of documents with international authors (i.e., from other Arab and non-Arab countries) from the total number of documents for each country

was 45 from collaboration with Western Europe, followed by 32 with Northern America, and 31 from Asiatic region.

Table 3 displays the results of research areas of interests in which Environmental Science was the highest (930; $45.8 \%$ ), followed by Chemical Engineering (465; $22.9 \%$ ), and Chemistry $(380 ; 18.7 \%)$. The retrieved documents were published in 152 peer-reviewed journals registered in Scopus. Table 4 shows the ranking of the top ten journals where authors from the Arab world have published their works. There were $126(6.2 \%)$ documents published in the Desalination journal, 60 (3\%) in the Desalination and Water Treatment journal, and $55(2.7 \%)$ in the Journal of Hazardous Materials journal. Most of the journals in the list of top ten ranking journals (nine journals out of ten) had impact factors as pointed out in JCR 2014.
The list of the top ten most cited articles is listed in Table 5 (Amine et al. 2006; Bakkali et al. 2008; Banat 1995; Banat et al. 1996; Desai and Banat 1997; Fakhru'l-Razi et al. 2009; Gupta et al. 2010; Houas et al. 2001; Lachheb et al. 2002; Nasef and Hegazy 2004). The most cited review article (1493 citations at the date of analyzing data) was published in the Food and Chemical Toxicology journal, followed by articles published in the Microbiology and Molecular Biology Reviews journal (1135 citations), the Bioresource Technology journal (1013 citations), and the Applied Catalysis B: Environmental journal (831). Table 6 lists the top ten most productive institutions and organizations in the Arab world. The most productive institution was the National Research Centre, Egypt; followed by King Abdulaziz University, Saudi Arabia; and University of Sfax, Tunisia. 
Table 2 Collaboration between Arab countries and non-Arab countries in industrial wastewater research

\begin{tabular}{|c|c|c|c|}
\hline $\begin{array}{l}\text { Region/ } \\
\text { country }^{\mathrm{a}}\end{array}$ & $\begin{array}{l}\text { No. of } \\
\text { documents (\%) }\end{array}$ & Region/country & $\begin{array}{l}\text { No. of } \\
\text { documents (\%) }\end{array}$ \\
\hline $\begin{array}{l}\text { Western } \\
\text { Europe }\end{array}$ & $423(20.82)^{\mathrm{b}}$ & Latin America & $21(1.03)^{\mathrm{b}}$ \\
\hline France & 239 (11.71) & Mexico & $14(0.69)$ \\
\hline UK & $57(2.81)$ & Brazil & $3(0.15)$ \\
\hline Spain & $47(2.31)$ & Haiti & $1(0.05)$ \\
\hline Germany & $44(2.17)$ & Guadeloupe & $1(0.05)$ \\
\hline Italy & $25(1.23)$ & Ecuador & $1(0.05)$ \\
\hline Netherlands & $11(0.54)$ & Colombia & $1(0.05)$ \\
\hline Belgium & $11(0.54)$ & Argentina & $1(0.05)$ \\
\hline Switzerland & $10(0.49)$ & Panama & $1(0.05)$ \\
\hline Sweden & $8(0.39)$ & Pacific region & $18(0.89)^{\mathrm{b}}$ \\
\hline Greece & $6(0.3)$ & Australia & $14(0.69)$ \\
\hline Portugal & $6(0.3)$ & New Zealand & $5(0.25)$ \\
\hline Denmark & $5(0.25)$ & Eastern Europe & $18(0.89)^{\mathrm{b}}$ \\
\hline Austria & $4(0.2)$ & Russia Federation & $6(0.3)$ \\
\hline Ireland & $4(0.2)$ & Poland & $4(0.2)$ \\
\hline Finland & $1(0.05)$ & Hungary & $2(0.1)$ \\
\hline Malta & $1(0.05)$ & Slovakia & $2(0.1)$ \\
\hline $\begin{array}{l}\text { North } \\
\text { America }\end{array}$ & $166(8.17)^{\mathrm{b}}$ & Czech Republic & $1(0.05)$ \\
\hline USA & $127(6.25)$ & Bulgaria & $1(0.05)$ \\
\hline Canada & $49(2.41)$ & Bosnia and Herzegovina & $1(0.05)$ \\
\hline Asiatic region & $152(7.48)^{\mathrm{b}}$ & Ukraine & $1(0.05)$ \\
\hline India & $52(2.56)$ & Serbia & $1(0.05)$ \\
\hline Malaysia & $29(1.43)$ & Africa & $15(0.74)^{\mathrm{b}}$ \\
\hline China & $28(1.38)$ & South Africa & $3(0.15)$ \\
\hline Japan & $19(0.94)$ & Côte d'Ivoire & $2(0.1)$ \\
\hline South Korea & $16(0.79)$ & Ghana & $2(0.1)$ \\
\hline Pakistan & $9(0.44)$ & Kenya & $2(0.1)$ \\
\hline Hong Kong & $6(0.30)$ & Nigeria & $2(0.1)$ \\
\hline Sri Lanka & $6(0.3)$ & Ethiopia & $1(0.05)$ \\
\hline Thailand & $3(0.15)$ & Burkina Faso & $1(0.05)$ \\
\hline Singapore & $2(0.1)$ & Senegal & $1(0.05)$ \\
\hline Taiwan & $2(0.1)$ & Tanzania & $1(0.05)$ \\
\hline Bangladesh & $2(0.1)$ & Middle East & $13(0.64)^{b}$ \\
\hline Vietnam & $2(0.1)$ & Turkey & $6(0.3)$ \\
\hline Indonesia & $1(0.05)$ & Iran & $4(0.2)$ \\
\hline Laos & $1(0.05)$ & Israel & $3(0.15)$ \\
\hline Kazakhstan & $1(0.05)$ & Arab-Arab & $157(7.7)$ \\
\hline Uzbekistan & $1(0.05)$ & Arab-Arab & $157(7.7)$ \\
\hline
\end{tabular}

${ }^{a}$ The study identified 715 (35.19\%) documents with 66 countries in Arab/non-Arab country collaborations

${ }^{\mathrm{b}}$ Total for all regions exceeds $35.19 \%$ as data are overlapping due to multi-country collaboration

Table 7 presents the results of a comparative analysis between the three most productive countries in the Arab world (Egypt, Saudi Arabia, and Tunisia) and three non-Arab Middle Eastern countries (Turkey, Israel, and Iran) with regard to number of published documents, citations, $h$-index, collaboration countries, and research output from collaboration. Figure 2 displays the evolution of scientific research in industrial wastewater in the three most productive countries from the Arab world (Egypt, Saudi Arabia, and Tunisia) and three non-Arab Middle Eastern countries (Turkey, Iran, and Israel). A comparison for the growth of rate of citations between the three most productive countries from the Arab world (Egypt,
Table 3 Ranking of areas of interests of the published research in the field of industrial wastewater within the period of the study

\begin{tabular}{lll}
\hline $\mathrm{SCR}^{\mathrm{a}}$ & Areas of interests & Number (\%) \\
\hline 1st & Environmental Science & $930(45.8)$ \\
2nd & Chemical Engineering & $465(22.9)$ \\
3rd & Chemistry & $380(18.7)$ \\
4th & Engineering & $333(16.4)$ \\
5th & Agricultural and Biological Sciences & $292(14.4)$ \\
6th & Materials Science & $231(11.4)$ \\
7 th & Biochemistry, Genetics, and Molecular Biology & $222(10.9)$ \\
8th & Earth and Planetary Sciences & $219(10.8)$ \\
9th & Energy & $117(5.8)$ \\
10th & Immunology and Microbiology & $115(5.7)$ \\
\hline
\end{tabular}

SCR standard competition ranking

${ }^{\text {a }}$ Equal areas of interests have the same ranking number, and then, a gap is left in the ranking numbers

${ }^{\mathrm{b}}$ Total exceeds $100 \%$ as data are overlapping due to multi-discipline interaction

Saudi Arabia, and Tunisia) and three non-Arab Middle Eastern countries (Turkey, Iran, and Israel) is illustrated in Fig. 3.

\section{Discussion}

This study is an attempt to measure the performance indicators related to the Arab world research productivity in industrial wastewater research. Our approach was to

Table 4 Ranking of top 10 journals in which industrial wastewaterrelated articles were published

\begin{tabular}{llll}
\hline SCR $^{\mathrm{a}}$ & Journal & Frequency & $\begin{array}{l}\text { IF } \\
(2014)^{\mathrm{b}}\end{array}$ \\
\hline 1st & Desalination & $126(6.2)$ & 3.756 \\
2nd & Desalination and Water Treatment & $60(3.0)$ & 1.173 \\
3rd & Journal of Hazardous Materials & $55(2.7)$ & 4.529 \\
4th & Journal of Chemical Technology & $37(1.8)$ & 2.349 \\
& $\quad$ and Biotechnology & $25(1.2)$ & 4.321 \\
5th & Chemical Engineering Journal & $21(1.0)$ & 1.56 \\
6th & Environmental Technology & $21(1.0)$ & $\mathrm{NA}$ \\
6th & Revue Des Sciences De L Eau & $20(1.0)$ & 5.528 \\
8th & Water Research & $18(0.9)$ & 1.679 \\
9th & Environmental Monitoring and & $17(0.8)$ & 2.828 \\
& Assessment & & \\
10th & Environmental Science and Pollution & & \\
& Research & & \\
\hline
\end{tabular}

$S C R$ standard competition ranking, $N A$ not available, $I F$ impact factor

${ }^{a}$ Equal journals have the same ranking number, and then, a gap is left in the ranking numbers

${ }^{\mathrm{b}}$ The impact factor was reported according to Institute for Scientific Information (ISI) Journal Citation Report (JCR) 2014 
Table 5 Ranking of top ten cited articles in Scopus in the field of industrial wastewater research

\begin{tabular}{|c|c|c|c|c|c|}
\hline $\mathrm{SCR}^{\mathrm{a}}$ & $\begin{array}{l}\text { Name of authors } \\
\text { and year of } \\
\text { publication }\end{array}$ & Title & $\begin{array}{l}\text { Type of } \\
\text { document }\end{array}$ & Journal name & $\begin{array}{l}\text { Times } \\
\text { cited }\end{array}$ \\
\hline 1 st & $\begin{array}{l}\text { Bakkali, F. et al. } \\
\quad 2008\end{array}$ & Biological effects of essential oils - a review & Review & $\begin{array}{l}\text { Food and Chemical } \\
\text { Toxicology }\end{array}$ & 1493 \\
\hline 2nd & $\begin{array}{l}\text { Desai, J.D. and } \\
\text { Banat, I.M. } 1997\end{array}$ & Microbial production of surfactants and their commercial potential & Review & $\begin{array}{l}\text { Microbiology and } \\
\text { Molecular Biology } \\
\text { Reviews }\end{array}$ & 1135 \\
\hline $3 \mathrm{rd}$ & $\begin{array}{l}\text { Banat, I.M. et al. } \\
\quad 1996\end{array}$ & Microbial decolorization of textile-dye-containing effluents: a review & Article & $\begin{array}{l}\text { Bioresource } \\
\text { Technology }\end{array}$ & 1013 \\
\hline 4th & $\begin{array}{l}\text { Houas, A. et al. } \\
2001\end{array}$ & Photocatalytic degradation pathway of methylene blue in water & Article & $\begin{array}{l}\text { Applied Catalysis B: } \\
\text { Environmental }\end{array}$ & 831 \\
\hline 5th & $\begin{array}{l}\text { Lachheb, H. et al. } \\
2002\end{array}$ & $\begin{array}{l}\text { Photocatalytic degradation of various types of dyes (alizarin S, crocein } \\
\text { orange } \mathrm{G} \text {, methyl red, Congo red, and methylene blue) in water by UV- } \\
\text { irradiated titania }\end{array}$ & Article & $\begin{array}{l}\text { Applied Catalysis B: } \\
\text { Environmental }\end{array}$ & 677 \\
\hline 6th & Banat, I.M. 1995 & $\begin{array}{l}\text { Biosurfactants production and possible uses in microbial enhanced oil } \\
\text { recovery and oil pollution remediation: a review }\end{array}$ & Review & $\begin{array}{l}\text { Bioresource } \\
\text { Technology }\end{array}$ & 352 \\
\hline 7th & $\begin{array}{l}\text { Nasef, M.M., } \\
\text { Hegazy, E.-S.A. } \\
2004\end{array}$ & $\begin{array}{l}\text { Preparation and applications of ion exchange membranes by radiation- } \\
\text { induced graft copolymerization of polar monomers onto non-polar films }\end{array}$ & Review & $\begin{array}{l}\text { Progress in Polymer } \\
\text { Science (Oxford) }\end{array}$ & 341 \\
\hline 8th & $\begin{array}{l}\text { Gupta, V.K. et al. } \\
2010\end{array}$ & $\begin{array}{l}\text { Adsorption studies on the removal of hexavalent chromium from aqueous } \\
\text { solution using a low-cost fertilizer industry waste material }\end{array}$ & Article & $\begin{array}{l}\text { Journal of Colloid and } \\
\text { Interface Science }\end{array}$ & 264 \\
\hline 9th & $\begin{array}{l}\text { Fakhru'l-Razi, A. } \\
\text { et al. } 2009\end{array}$ & Review of technologies for oil- and gas-produced water treatment & Review & $\begin{array}{l}\text { Journal of Hazardous } \\
\text { Materials }\end{array}$ & 263 \\
\hline 10th & $\begin{array}{l}\text { Amine, A. et al. } \\
2006\end{array}$ & $\begin{array}{l}\text { Enzyme inhibition-based biosensors for food safety and environmental } \\
\text { monitoring }\end{array}$ & Review & $\begin{array}{l}\text { Biosensors and } \\
\text { Bioelectronics }\end{array}$ & 253 \\
\hline
\end{tabular}

SCR standard competition ranking

${ }^{a}$ Equal articles have the same ranking number, and then, a gap is left in the ranking numbers

source publications and to gather systematic data from Scopus databases, employing the bibliometric techniques which are used frequently to examine the trends and the

Table 6 Ranking of the top ten highly productive institutions in the field of industrial wastewater research during the period of the study

\begin{tabular}{|c|c|c|c|}
\hline $\mathrm{SCR}^{\mathrm{a}}$ & Name of institution & Country & $\begin{array}{l}\text { No. of } \\
\text { documents (\%) }\end{array}$ \\
\hline 1 st & National Research Centre & Egypt & $169(8.32)$ \\
\hline 2nd & King Abdulaziz University & Saudi Arabia & $75(3.69)$ \\
\hline $3 \mathrm{rd}$ & University of Sfax & Tunisia & $72(3.54)$ \\
\hline 4th & Ain Shams University & Egypt & $52(2.56)$ \\
\hline 5 th & Alexandria University & Egypt & $48(2.36)$ \\
\hline 6th & King Saud University & Saudi Arabia & $46(2.26)$ \\
\hline 7th & $\begin{array}{l}\text { King Fahd University of } \\
\text { Petroleum } \\
\text { and Minerals }\end{array}$ & Saudi Arabia & $42(2.07)$ \\
\hline $8 \mathrm{~h}$ & $\begin{array}{l}\text { Kuwait Institute for } \\
\text { Scientific Research }\end{array}$ & Kuwait & $40(1.97)$ \\
\hline 9th & $\begin{array}{l}\text { United Arab Emirates } \\
\text { University }\end{array}$ & $\begin{array}{l}\text { United Arab } \\
\text { Emirates }\end{array}$ & $37(1.82)$ \\
\hline 9th & $\begin{array}{l}\text { Ecole Nationale } \\
\text { d'Ingenieurs de Sfax }\end{array}$ & Tunisia & $37(1.82)$ \\
\hline
\end{tabular}

SCR standard competition ranking

${ }^{a}$ Equal institutions have the same ranking number, and then, a gap is left in the ranking numbers scientific output (Gunn et al. 2015) in many disciplines of science (Sweileh et al. 2015; Zheng et al. 2015; Zyoud et al. 2015; Zyoud and Fuchs-Hanusch 2015). Qualitative and quantitative parameters have been considered to measure and compare the performance of research activities originated from researches in the Arab world against other regions. The improving of the research activities and the scientific quality is a pre-condition to open up new fields of knowledge (Tijssen et al. 2002).

This study has addressed the issue of evaluating the quantity of industrial wastewater-based research in the Arab world by utilizing the total amounts of publications and the quality of research by utilizing the impact factors, $h$-index, and citation rates. The performance indicators, in terms of research productivity, showed that research activities in this field are insufficient or even ignored in some Arab countries. The research activities in industrial wastewater at the Arab world level have begun very modestly from the middle of seventieth of the twentieth century and developed gradually. The launch of these activities was too delayed when compared to the beginnings of research activities in this field at global level. It is to know that the first documented article in Scopus databases, related to industrial wastewater research at global level, was in 1931, whereas the first published article by researches from the Arab world was in 1976. In spite that time lags 


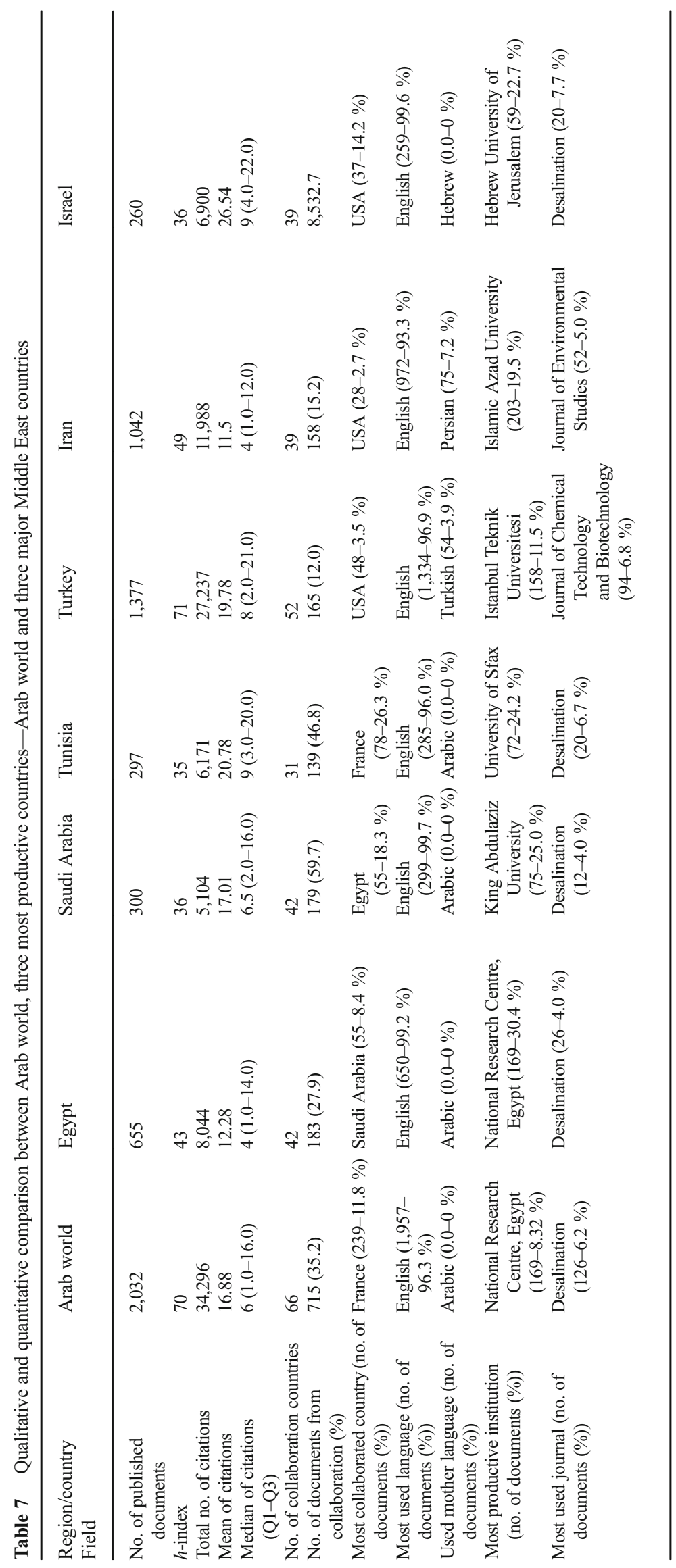


Fig. 2 Number of published articles and review articles in industrial wastewater research for most productive Arab countries and non-Arab Middle Eastern countries

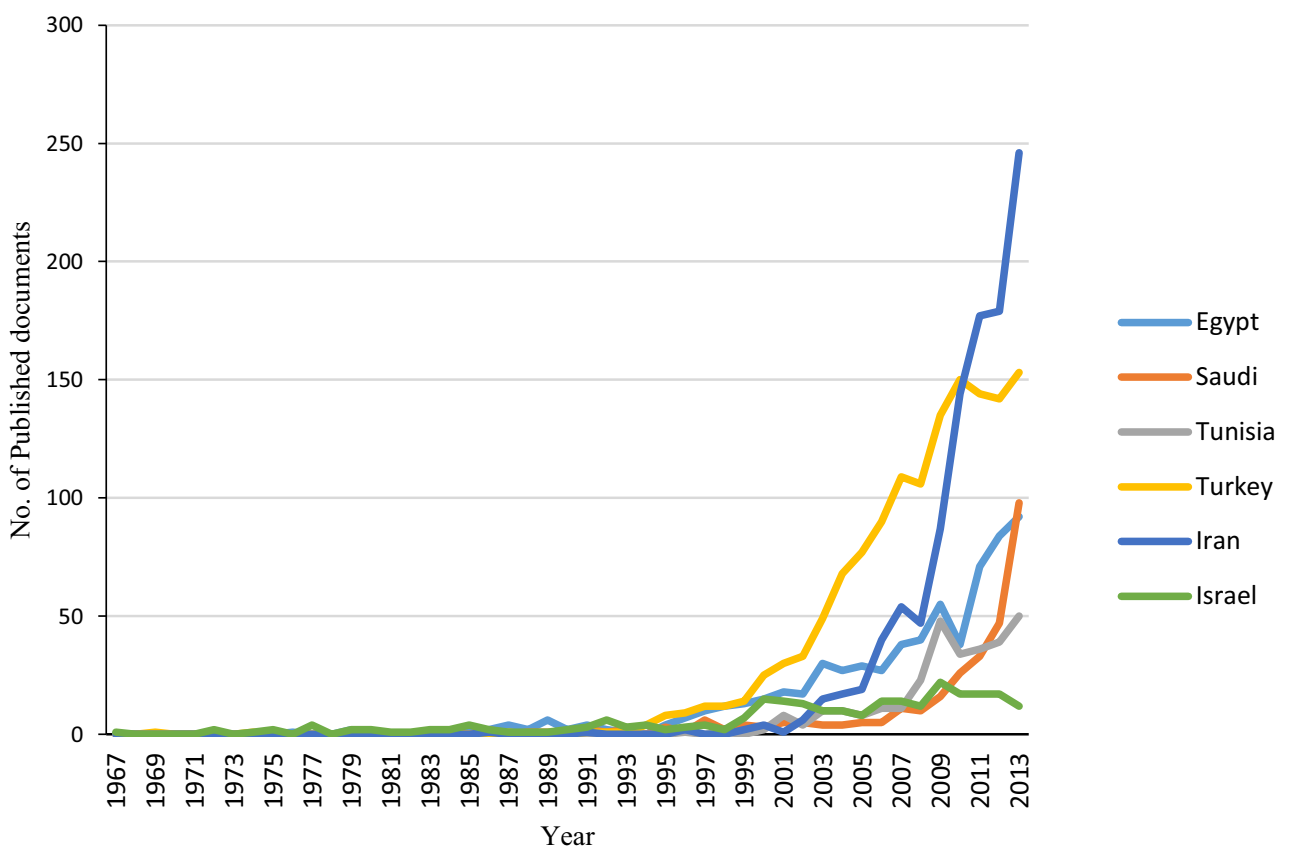

are observed, this launch was concurrent with the beginning of the real momentum in industrial wastewater research at global level which was trivial and sporadic before the sixteenth of the twentieth century. It was relatively in parallel with the start of research activities in this field in other major Middle East countries.

Despite the encouraging indicators of increasing research productivity, and the encouraging trends shown by citation indicators during the last period, there are large gaps in productivity between the developed and developing countries as pointed out by data announced by the Institute for Scientific Information (Langer et al. 2004). The Arab world is responsible for a meager $1.4 \%$ of the scientific papers published worldwide (Boumedjout 2010). The increase in research activities in industrial wastewater from the Arab region could be associated with the general increase in research and publication activity (Benamer and Bakoush 2009). The contribution in global scientific research from the Arab world in industrial wastewater showed a figure of $3.6 \%$, which is better than the Arab world contribution in solid waste research that showed a figure of $2.35 \%$ (Zyoud et al. 2015), and is much less than the Arab world contribution in desalination research, which amounted to $16.0 \%$ (Zyoud and Fuchs-Hanusch 2015). This figure is also better than the results in medical research; Arab countries currently produce less than $1 \%$ of citations in the world and contribute less than $0.5 \%$ of papers appearing in the 200 leading medical journals (Maziak 2005). These findings were also proved by numerous bibliometric studies in medical research (Sweileh et al.
Fig. 3 Developing of citations for published articles and review articles in industrial wastewater research for Arab world and most productive Arab countries and non-Arab Middle Eastern countries

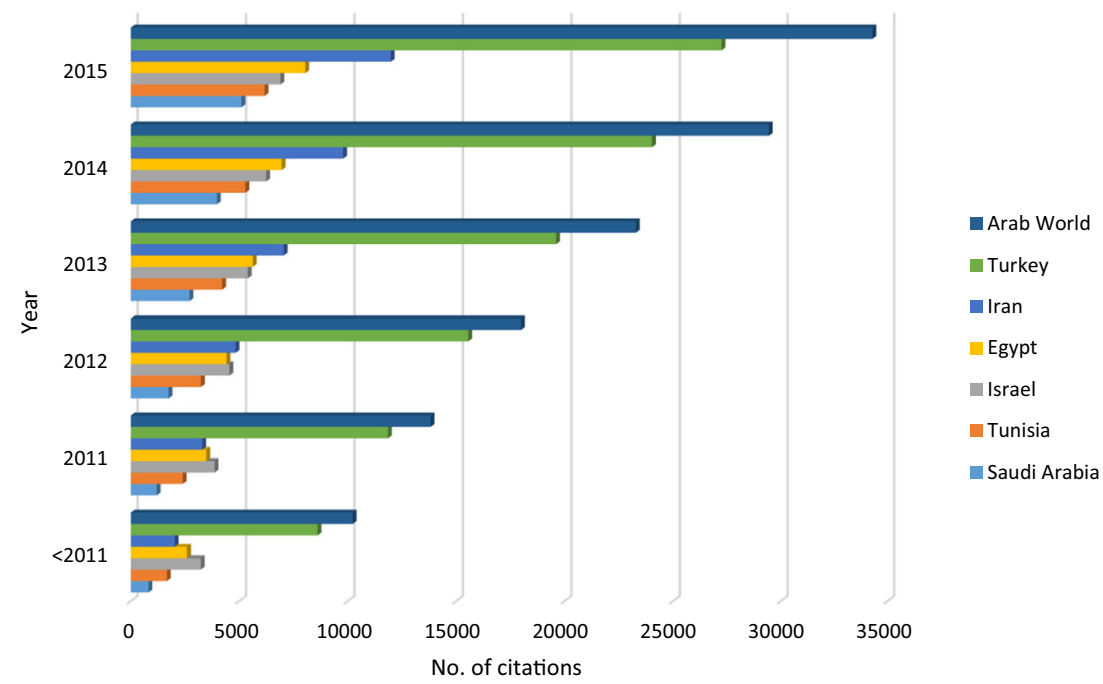


2015; Sweileh et al. 2014). Diabetes mellitus research output from the Middle Eastern Arab countries showed a figure of $0.75 \%$ of the total documents produced globally (Sweileh et al. 2014). The justification of the reasonably good figure in industrial wastewater research is explained by the interactions between industrial wastewater research and desalination research. It is proved that Arab countries excel in desalination research (Masood 2002).

The prevalent used language in industrial wastewater research by researchers from the Arab world was English. The English language is widely accepted as the international language of science and technology. It is the current global lingua franca of international scientific publications (Vanbaelen and Harrison 2015). Arab researchers tend to publish in English language to gain international credibility (Atwell et al. 2009). Research papers written in Arabic have restricted circulation as pointed out by the initiative of the Arab League Educational, Social, and Cultural Organization (ALESCO) to run workshops where leading-edge research is reported in Arabic, but this was anticipated making the proceedings inaccessible to the worldwide research community (Atwell et al. 2009). In Turkey and Iran, there is increase in using the mother languages in their research activities. The rapidly growing of using these languages could be justified by the increase in the number of journals from these two countries indexed in Scopus (Najari and Yousefvand 2013).

Egypt, Saudi Arabia, and Tunisia markedly showed higher rates of contributions in industrial wastewater research. In the case of Egypt, it has the most extensive research structure in the Arab world in terms of research and development units and has traditional strengths in chemistry and engineering research (Koenig 2007). Egypt is the second on its continent (after South Africa) in scientific production (Waast and Rossi 2010). The population size of Egypt is a vital factor among other factors in increasing the scientific research productivity since it depends on population, socioeconomic, or overall scientific activity of the country (Miró et al. 2009). The interests in industrial wastewater research in Egypt stem partially from developing numerous management programs for industrial wastewater. These management programs have been built to eliminate the risks imposed by industrial wastewater after constructing new industrial estates in the desert and to protect the ecosystem of the Nile river and delta from further degradation (El-Gohary et al. 2002). The heavy use of water in food industry made Egyptian researchers focus their efforts on developing new technologies to treat the wastewater effluents. Another important subject of research in Egypt is the agricultural wastewater treatment (Barceló and Petrovic 2011). Three institutions in Egypt claim top positions in the list of top ten institutions at the Arab world level. The National Research Center (NRC), which occupies the top position in the list, is the largest research center in the Middle East for science and technology. The center serves the national, regional, and international cooperation including technology transfer and membrane technology in water treatment (Lorenzo 2010).

Saudi Arabia is the most collaborated country with Egypt in industrial wastewater research. They have a strong research partnership. The annual joint research between the two countries has risen tenfold in the past decade and is accelerating (Adams 2012). The USA is the biggest partner outside the region for both countries (Adams 2012). This conclusion has also been demonstrated in this study where the USA has assumed the second position in collaboration with Egypt and Saudi Arabia. The study showed that $43(6.6 \%)$ and 31 (10.3\%) documents out of the total documents published by Egypt and Saudi Arabia, respectively, were in collaboration with the USA.

The oil refining and natural gas processing industries, as in Saudi Arabia, are responsible for approximately $38 \%$ of the annual industrial water withdrawals (Kajenthira et al. 2012). There are growing interests in industry sectors in Saudi Arabia to treat and reuse the industrial wastewater (Al-Ghasham et al. 2005). This will reduce their water demands from desalination plants and municipal sources and consequently reduce the costs and will save energy (Wichelns et al. 2015). With regard to scientific research and development, Saudi Arabia is progressing and has plans to increase funding for research to the amount of $2 \%$ of the total gross domestic product by 2015 (Alshayea 2013). The strategy of Saudi Arabia is setting up a base of science by localizing the best foreign capabilities and innovative research and development firms in knowledge villages (Waast and Rossi 2010). King Abdul-Aziz University of Saudi Arabia claims the second position in the list of most prolific institutions in the Arab world in industrial wastewater research. It is the home of center of excellence in desalination technology. These findings reflect the efforts of Saudi Arabia for the advancement of scientific research and the special consideration which has been given to scientific research in order to promote scientific innovation, as well as to develop universities and research centers (Alshayea 2013).

Tunisia is considered among the first countries in the Mediterranean region that established and implemented an integrated wastewater reuse policy (Kellis et al. 2013). It is recognized, along with Israel, as a leader in the area of wastewater reclamation and reuse (Shetty 2004). The classification of Tunisia as one of the least developed countries endowed with water resources in the Mediterranean basin is the driving force behind the intensive investment in industrial wastewater treatment research (Jemli et al. 2015). Tunisia has a pioneer institution which is one of the leading institutions in the field of environmental biotechnology in the African, Middle East, and North African regions. The Centre of Biotechnology of Sfax is working on developing new concepts for 
bioremediation of waste and wastewater, etc. The Sfax Laboratory of Environmental Bioprocesses concentrates its research on studying the biological system involved in aerobic and anaerobic degradation of municipal and industrial pollutants (Lorenzo 2010). The PROMEMBRANE project, which was funded by the European Union, with a primary objective to support and focus the current research and development activities on membrane technology for water treatment in the Mediterranean region, has affected positively in increasing research activities in Tunisia (Lorenzo 2010).

The collaboration patterns between Arab world and nonArab countries demonstrated high rates of collaboration with Western Europe region, mainly France. This could be explained by the active participation of the three Maghreb countries, Tunisia, Algeria, and Morocco, which contributed in $30 \%$ of the total research output from the Arab world. Their collaboration with France resulted in 215 (32.0\%) documents out of their research output. France was noted to be heavily associated with its former colonies in external research collaboration. The results of collaboration between France and Maghreb countries were compatible to the results of analysis conducted by Harford (2015) to examine the optimal collaboration in cancer control efforts across the Africa continent (Harford 2015). The USA took the second place in collaboration with the Arab world. The USA sustains as a major contributor in scientific collaboration due to its large productivity in scientific research (Gazni et al. 2012). The benefits of international collaboration are manifested in its powerful in bringing complementary expertise together to pursue and achieve higher-impact science research (Havemann et al. 2006). Additional benefits are in reducing the costs and saving the efficiency by reducing the duplication of equipment and expertise (Toope et al. 2012).

The screening of the Arab world performance in comparison with three non-Arab Middle Eastern countries (Turkey, Iran, and Israel) at country level shows a gap especially with comparison to the performance of Turkey. The performance of Tunisia, in spite of its limited resources and the size of its population, was unique. The adoption of European Union standards for water, wastewater, and solid waste management in Turkey, associated with the high rates of industrial wastewater $(75 \%)$ discharged without treatment, motivated researchers to study and examine new treatment technologies for highly polluted industrial wastewater (Malato et al. 2011).

The analysis provides an integrated perspective and interesting insights on the figuration and developing of industrial wastewater research, figures of research activity distribution, qualitative aspects, and collaboration trends. In bibliometric analyses, several limitations could be raised. One of these limitations is the employing of Scopus databases only. This study cannot take into consideration all literatures published in other databases which might have contribution to industrial wastewater research in the Arab world.

\section{Conclusions}

A remarkable evidence of commitment to increase research activities in industrial wastewater research has been noticed in the Arab world. A dramatic boost in the number of published documents by researchers from the Arab world took place in the last 10 years, and the quality indicators of these researches are promising in the field of industrial wastewater. Egypt, Saudi Arabia, and Tunisia are the leading Arab countries in this regard. Despite the optimistic outlook, there are still gaps between the Arab countries and other countries in the same region and at global level. Research institutions in Arab world should strengthen collaboration networks with their counterparts in developed countries to promote research activities. The governments should invest in industrial wastewater research as a requirement and not a choice. These investments are necessary to eliminate the potential risks of industrial wastewaters and to optimize the use of water resources. This paper serves as a benchmark which makes comparisons among the Arab world countries and other major countries in the region. The applied bibliometric methodology is applicable to other subjects in environmental realm.

Acknowledgments Open access funding provided by Graz University of Technology.

Open Access This article is distributed under the terms of the Creative Commons Attribution 4.0 International License (http:// creativecommons.org/licenses/by/4.0/), which permits unrestricted use, distribution, and reproduction in any medium, provided you give appropriate credit to the original author(s) and the source, provide a link to the Creative Commons license, and indicate if changes were made.

\section{References}

Abramov VO, Abramova AV, Keremetin PP, Mullakaev MS, Vexler GB, Mason TJ (2014) Ultrasonically improved galvanochemical technology for the remediation of industrial wastewater. Ultrason Sonochem 21:812-818

Adams J (2012) Collaborations: the rise of research networks. Nature 490:335-336

Al-Ghasham T, Clark B, Al-Saud AA, Al-Hajji M, Al-Muaibid J, Gauthier C (2005) Industrial wastewater treatment for reuse, assessment study in a Saudi Aramco facility. Saudi Aramco J Technol 7: $52-60$

Alshayea A (2013) Scientific research in the Kingdom of Saudi Arabia: potential for excellence and indicators of underdevelopment. High Educ Stud 3:5539

Al-Zubari WK (1998) Towards the establishment of a total water cycle management and re-use program in the GCC countries. Desalination 120:3-14

Amine A, Mohammadi H, Bourais I, Palleschi G (2006) Enzyme inhibition-based biosensors for food safety and environmental monitoring. Biosens Bioelectron 21:1405-1423

Arnold LK (1931) Agricultural wastes in industry. J Chem Educ 8:23112324 
Atwell E, Al-Sulaiti L, Sharoff S (2009): Arabic and Arab English in the Arab world, Proceedings of CL2009 International Conference on Corpus Linguistics. UCREL, Lancaster University.

Azizullah A, Richter P, Häder D-P (2015) Effects of long-term exposure to industrial wastewater on photosynthetic performance of Euglena gracilis measured through chlorophyll fluorescence. J Appl Phycol 27:303-310

Bakkali F, Averbeck S, Averbeck D, Idaomar M (2008) Biological effects of essential oils - A review. Food Chem Toxicol 46:446-475

Banat IM (1995) Biosurfactants production and possible uses in microbial enhanced oil recovery and oil pollution remediation: a review. Bioresource Technol 51:1-12

Banat IM, Nigam P, Singh D, Marchant R (1996) Microbial decolorization of textile-dye-containing effluents: a review. Bioresource Technol 58:217-227

Barakat M (2011) New trends in removing heavy metals from industrial wastewater. Arab J Chem 4:361-377

Barceló D, Petrovic M (2011): Waste water treatment and reuse in the Mediterranean region, 14. Springer Science \& Business Media.

Benamer HT, Bakoush O (2009) Arab nations lagging behind other Middle Eastern countries in biomedical research: a comparative study. BMC Med Res Methodol 9:26

Boumedjout H (2010): Arab world must innovate in science, says UNESCO. Nature Middle East

Brillas E, Sirés I (2015) Electrochemical removal of pharmaceuticals from water streams: reactivity elucidation by mass spectrometry. TrAC Trends Anal Chem 70:112-121

De Battisti F, Salini S (2013) Robust analysis of bibliometric data. Statistical Methods Applications 22:269-283

Desai JD, Banat IM (1997) Microbial production of surfactants and their commercial potential. Microbiol Mol Biol R 61:47-64

Doheim M (1976) Fluidization in the non-ferrous mineral processing and metal industry. Int J Miner Process 3:313-341

Dvořák L, Svojitka J, Wanner J, Wintgens T (2013) Nitrification performance in a membrane bioreactor treating industrial wastewater. Water Res 47:4412-4421

Egghe L (2006) An improvement of the h-index: the g-index. ISSI Newsletter 2:8-9

El-Gohary F, Wahaab R, Nasr F, Ali H (2002) Three Egyptian industrial wastewater management programmes. Environmentalist 22:59-65

Elsevier (2015) What content is included in Scopus

Fakhru'l-Razi A, Pendashteh A, Abdullah LC, Biak DRA, Madaeni SS, Abidin ZZ (2009) Review of technologies for oil and gas produced water treatment. J Hazard Mater 170:530-551

García-García A, Martínez-Miranda V, Martínez-Cienfuegos IG, Almazán-Sánchez PT, Castañeda-Juárez M, Linares-Hernández I (2015) Industrial wastewater treatment by electrocoagulationelectrooxidation processes powered by solar cells. Fuel 149:46-54

García-Morales M, Roa-Morales G, Barrera-Díaz C, Bilyeu B, Rodrigo M (2013) Synergy of electrochemical oxidation using boron-doped diamond (BDD) electrodes and ozone $\left(\mathrm{O}_{3}\right)$ in industrial wastewater treatment. Electrochem Commun 27:34-37

Gazni A, Sugimoto CR, Didegah F (2012) Mapping world scientific collaboration: authors, institutions, and countries. J Am Soc Inf Sci Technol 63:323-335

Gunn M, Lim M, Cross D, Goldman M (2015) Benchmarking the scientific output of the Innovative Medicines Initiative. Nat Biotechnol 33:811-812

Gupta VK, Rastogi A, Nayak A (2010) Adsorption studies on the removal of hexavalent chromium from aqueous solution using a low cost fertilizer industry waste material. J Colloid Interf Sci 342:135-141

Harford JB (2015) Barriers to overcome for effective cancer control in Africa. Lancet Oncol 16:e385-e393

Havemann F, Heinz M, Kretschmer H (2006) Collaboration and distances between German immunological institutes - a trend analysis. J Biomed Discov Collab 1:6
Hirsch JE (2005) An index to quantify an individual's scientific research output. Proc Natl Acad Sci U S A 102:16569-16572

Houas A, Lachheb H, Ksibi M, Elaloui E, Guillard C, Herrmann JM (2001) Photocatalytic degradation pathway of methylene blue in water. Appl Catal B: Environ 31:145-157

Jemli M, Sabbahi S, Ben Ayed L (2015) Performance of urban wastewater treatment of four activate sludge treatment plants in Tunisia. Int J Wastewater Treat 1:104

Kajenthira A, Siddiqi A, Anadon LD (2012) A new case for promoting wastewater reuse in Saudi Arabia: bringing energy into the water equation. J Environ Manag 102:184-192

Kellis M, Kalavrouziotis I, Gikas P (2013) Review of wastewater reuse in the Mediterranean countries, focusing on regulations and policies for municipal and industrial applications. Global NEST J 15:333-350

Koenig R (2007) Egypt plans a shakeup of research programs. Science 317:30

Krzemińska D, Neczaj E, Borowski G (2015) Advanced oxidation processes for food industrial wastewater decontamination. J Ecol Eng 16:61-71

Lachheb H, Puzenat E, Houas A, Ksibi M, Elaloui E, Guillard C, Herrmann JM (2002) Photocatalytic degradation of various types of dyes (Alizarin S, Crocein Orange G, Methyl Red, Congo Red, Methylene Blue) in water by UV-irradiated titania. Appl Catal B: Environ 39:75-90

Langer A, Díaz-Olavarrieta C, Berdichevsky K, Villar J (2004) Why is research from developing countries underrepresented in international health literature, and what can be done about it? Bull World Health Organ 82:802-803

Lin H, Gao W, Meng F, Liao B-Q, Leung K-T, Zhao L, Chen J, Hong H (2012) Membrane bioreactors for industrial wastewater treatment: a critical review. Crit Rev Environ Sci Technol 42:677-740

Lorenzo A (2010) Membrane technology in water treatment in the Mediterranean region (ProMembrane). IWA Publishing, London, UK

Malato S, Oller I, Fernández-Ibánez P, Fuerhacker M (2011): Technologies for advanced wastewater treatment in the Mediterranean region, waste water treatment and reuse in the Mediterranean region. Springer, 1-28

Masood E (2002) Arab science: blooms in the desert. Nature 416:120-122

Maziak W (2005) Science in the Arab world: vision of glories beyond. Science 308:1416-1418

Meho LI, Rogers Y (2008) Citation counting, citation ranking, and h-index of human-computer interaction researchers: a comparison of Scopus and Web of Science. J Am Soc Inf Sci Technol 59:1711-1726

Minguillo D, Tijssen R, Thelwall M (2015) Do science parks promote research and technology? A scientometric analysis of the UK. Scientometrics 102:701-725

Miró Ò, Montori E, Ramos X, Galicia M, Nogué S (2009) Trends in research activity in toxicology and by toxicologists in seven European countries. Toxicol Lett 189:1-4

Najari A, Yousefvand M (2013) Scientometrics study of impact of journal indexing on the growth of scientific productions of Iran. Iran J Public Health 42:1134-1138

Nasef MM, Hegazy ESA (2004) Preparation and applications of ion exchange membranes by radiation-induced graft copolymerization of polar monomers onto non-polar films. Prog Polym Sci 29:499 561

Obermeyer CM, Bott S, Sassine AJ (2015) Arab adolescents: health, gender, and social context. J Adolesc Health 57:252-262

Oke I, Olarinoye N, Adewusi S (2008) Adsorption kinetics for arsenic removal from aqueous solutions by untreated powdered eggshell. Adsorption 14:73-83

Pedersen AJ (2003) Characterization and electrodialytic treatment of wood combustion fly ash for the removal of cadmium. Biomass Bioenergy 25:447-458

Phetphaisit CW, Yuanyang S, Chaiyasith WC (2016) Polyacrylamido-2methyl-1-propane sulfonic acid-grafted-natural rubber as bio- 
adsorbent for heavy metal removal from aqueous standard solution and industrial wastewater. J Hazard Mater 301:163-171

Qian F, He M, Song Y, Tysklind M, Wu J (2015) A bibliometric analysis of global research progress on pharmaceutical wastewater treatment during 1994-2013. Environ Earth Sci 73:4995-5005

Roy A, Bhattacharya J (2015) Nanotechnology in industrial wastewater treatment. IWA Publishing, london, UK

Saleh MA (2015) Pemphigus in the Arab world. J Dermatol 42:27-30

Shetty S (2004): 15. Treated wastewater use in Tunisia: lessons learned and the road ahead. Wastewater use in irrigated agriculture: confronting the livelihood and environmental realities, 163

Sweileh WM, Zyoud SH, Al-Jabi SW, Sawalha AF (2014) Bibliometric analysis of diabetes mellitus research output from Middle Eastern Arab countries during the period (1996-2012). Scientometrics 101: 819-832

Sweileh WM, Al-Jabi SW, Abuzanat A, Sawalha AF, AbuTaha AS, Ghanim MA, Zyoud SH (2015) Assessment of research productivity of Arab countries in the field of infectious diseases using Web of Science database. Infect Dis Poverty 4:2

Szafnicki K, Narce C (2006) Towards a "crippled-mode" operation of an industrial wastewater treatment plant. Water Res 40:579-587

Tijssen R, Visser M, van Leeuwen T (2002) Benchmarking international scientific excellence: are highly cited research papers an appropriate frame of reference? Scientometrics 54:381-397

Toope SJ, Tan CC, Fedoroff NV (2012) Improving Asia-Pacific science collaboration. Science 336:38-39

UIS (2005) What do bibliometric indicators tell us about world scientific output? Bulletin on Science and Technology Statistics, issue no 2, September 2005. UNESCO Institute for Statistics, Montreal van Raan AF (2005) For your citations only? Hot topics in bibliometric analysis. Measurement 3:50-62

Vanbaelen R, Harrison J (2015): Development of a graduate school EAP course for engineers, Professional Communication Conference (IPCC), 2015 I.E. International. IEEE, 1-7

Waast R, Rossi P-L (2010) Scientific production in Arab countries a bibliometric perspective. Sci Technol Soc 15:339-370

Wallin JA (2005) Bibliometric methods: pitfalls and possibilities. Basic Clin Pharmacol Toxicol 97:261-275

Wichelns D, Drechsel P, Qadir M (2015): Wastewater: economic asset in an urbanizing world, wastewater. Springer, 3-14

World Bank (2011): Water resuse in the Arab world: from principle to practice, Dubai, United Arab Emirates

Wu C, Gao Z, Zhou Y, Liu M, Song J, Yu Y (2015) Treatment of secondary effluent from a petrochemical wastewater treatment plant by ozonation-biological aerated filter. J Chem Technol Biotechnol 90: 543-549

Zheng T, Wang J, Wang Q, Nie C, Smale N, Shi Z, Wang X (2015) A bibliometric analysis of industrial wastewater research: current trends and future prospects. Scientometrics 105:863-882

Zyoud SH, Fuchs-Hanusch D (2015) Estimates of Arab world research productivity associated with desalination: a bibliometric analysis. IDA Journal of Desalination and Water Reuse 7:3-16

Zyoud SH, Al-Jabi SW, Sweileh WM, Al-Khalil S, Zyoud SH, Sawalha AF, Awang R (2015) The Arab world's contribution to solid waste literature: a bibliometric analysis. J Occup Med Toxicol 10:35 